\title{
Influence of Plant Age, Tomato Variety and NematodeInoculum Density on Pathogenicity of Meloidogyneincognitaon Tomato in AbakalikiAgro-Ecology
}

\author{
Nwode, S. E. ${ }^{1}$, E. O. Okporie ${ }^{2}$, S. C. Chukwu ${ }^{2}$ and G. C. Onyishi ${ }^{3}$ \\ ${ }^{1}$ Secondary Education Board, Abakaliki, Nigeria. \\ ${ }^{2}$ Crop Production and Landscape Management Department, \\ Ebonyi State University, Abakaliki, Nigeria. \\ ${ }^{3}$ Crop Science and Technology Department, \\ Federal University of Technology, Owerri, Nigeria.
}

\begin{abstract}
Pathogenicity of Meloidogyne incognita on tomato which is influenced by plant age, tomato variety and nematode inoculum density was studied. The experiment was a $2 \times 3 \times 4$ factorial in completely randomized design with 4 replications. Two tomato varieties: Roma VF and Pimpinellifolium at 4, 6 and 8 weeks old were variously treated with $O, 500,1000$ and 1500 nematode infective larvae. Results showed that root gall damage on both tomato varieties increased with increased inoculum density. The same was true for number of days to $50 \%$ flowering. An inverse relationship however occurred between mean root length, weight, percentage dry matter and nematode inoculum density. The same was true for mean shoot dry matter, fresh weight, length and number of branches/plant. Plants inoculated at 6 weeks after sowing into the container had highest galling response which was significantly different from others.
\end{abstract}

Key words: Meloidogynesp, Lycopersiconesculentum, Lycopersiconpimpinellifolium.

\section{Introduction}

Tomato (Lycopersiconesculentum Mill) is one of the most important and leading vegetable crops in the world [1]. It is considered a versatile crop because of the various ways in which it is consumed and the extent of its production around the world [2]. World production of tomato as estimated by FAO in 1990 stood at just over 69 million metric tons harvested from a total planted area of almost 3 million ha at an average yield of 24.69 tons per ha [3]. However, production on a geographical basis has continued to be unbalanced favouring mostly in the temperate regions. Leading tomato producers are still to be found in countries with cooler climates. Comparisons of yield trends between farmers in the temperate and tropical regions shows that yield in the tropics are much lower than in the temperate zones [4]. The average yield for the temperate zones is 127.36 ton per ha higher when compared to 23.5 ton per ha for the topics [1]. Many factors contribute to low tomato production in the tropics. These include high temperature, excessive rainfall, pests and diseases, poor cultural practices and low soil fertility. Increasing night and daytime periods are common phenomena in the tropics and which adversely affect tomatoes by reducingflowering, fruiting and yield[5]. The heavytropical rains tend to cause mechanical damagesespecially to the flowers. Prevailing high humidity createsan environment conducive to disease and pest infestations [1].

The root-knot nematodes Meloidogynespeciesconstitute the major nematode problem in developing countries.

Three species namely: Meloidogyneincognita,MeloidogynearenariaandMeloidogynejavanicawerereported of severe attack on vegetable crops in Nsukka[6]. Root-knot nematodes are major crop pests worldwide and cause root galling, root stunting andloss of yield [6]. The most common speciesis $M$. incognita, which causes considerable losses inmany crops. Root-knot nematodes (Meloidogynespecies) are distributed worldwide and have a collectivehost range that includes nearly all crop plants. Thesymptoms include root galling, early senescence,chlorosis, unthirfting growth, stunted appearance,reduction in fruit number and size and generalsusceptibility to rot and wilt-inducing pathogens[7]. Root galling by the nematode impairabsorption and upward translocation of water, mineralsand assimilates $[8,9 \& 10]$. Meloidogyneproblem is furtheraggravated in agricultural soils due to its interaction withindigenous soil micro flora. The combination of sandysoils, high temperatures and intensive cultivation ofnematode - susceptible crop varieties can lead to severeroot-knot nematode problems and weeds quickly build up[11 \& 12]. In theCoachella and San Joaquin valleys, where nematodes -irrigation, M. incognita and $M$. javanicaare common anddamage numerous crops, especially in sandy soils[13].

Resistant crops have been economically effective in thecontrol of root-knot nematodes. The resistance of sometomatoes has been reported in Nigeria and elsewhere[14 \& 15]. In EL-Salvador, varieties of the wild speciesLycopersiconpimpinellifoliumhave been found to beresistant to Meloidogynespp. [16]. However, the 
successful use of resistant varietieswill depend on the biological races of Meloidogynespp.present in a given locality. This underscores the need forspecific screenings for resistance. One of the goals of theInternationalMeloidogyne Project (IMP) established in1975 includes devising control measures to curb themenace of Meloidogynein developing countries[17]. Plantage is an important factor impacting on the inoculums potential of $M$. incognita. The interaction between tomatogrowth and reproduction of $M$. incognita is dependentupon plant age and cultivar resistance. The complexbiotic factors such as plant species, plant age, hostcultivars and infection with plant pathogen affected rootcolonization[18 \& 19].

The objectives of this study were to:

i) determinethe age at which nematode makes thegreatest infection on the susceptibility of tomato cultivars.

ii) makea comparative study of the susceptibility of twotomato genotypes to $M$. incognita, and;

iii) probethe information that a wild tomato genotype isnot usually susceptible to M. incognita.

\section{Materials And Methods}

The study was conducted at the plant house of the Department ofCrop Production and Landscape Management, EbonyiStateUniversity, Abakaliki, located $477 \mathrm{~m}$ above sea level and lies withinlongitude of $08^{\circ}$ $65^{\prime} \mathrm{E}$ and latitude $06^{\circ} 04^{\prime} \mathrm{N}$ in the derived SavannaZone of South Eastern Nigeria.

\section{Preparation of nematode inoculum}

Abakaliki population of $M$. incognita race II maintained on begoniaplants (Begonia rex-cultorum) serves as inocula sources. Thenematode species was multiplied and maintained on IndianSpinach (Basselarubra) in steam sterilized soil. Heavily galled rootsof the Indian spinach were gently freed from the soil. Some soilparticles adhering to the roots were removed by rinsing in tapwater. Galled roots were chopped into small pieces and put in awarren blender. Small quantity of water was added to the galledtissues and blended into slurry. In order to avoid inactivating theineffective nematode, the blending was done for $5 \mathrm{~s}$ only at eachinterval. The blended material was poured into $1000 \mathrm{ml}$ beaker andmore water added and stirred. Thirty milliliters $(30 \mathrm{ml})$ of thesuspension was poured into a nematode counting dish. Thenumber of the larvae was counted using a stereomicroscope. Theconcentration of the suspension was so regulated so that 30 mlsuspension contained approximately 1000 larvae as the mean fromthree counts. This was the inoculum level that was used toinoculate roots of the test plant.

\section{Source of planting materials}

The plant materials for the experiment were Roma VF tomato (L.esculentum) and a closely related wild species (L. pimpinellifolium).Both were sourced locally from the Department of Crop Science,University of Nigeria, Nsukka. Prior to planting, seeds were surfacesterilized separately in $0.5 \%$ chlorox for 5 min and washed threetimes in tap water. Six nursery baskets were provided. Eachnursery (basket) was filled with the steam sterilized soil mixture oftopsoil, cow- dung and river sand in the ratio of 3:2:1, respectivelyand watered before seeds were planted in it. Three lots of nurseryseeds of the two tomato cultivars were planted at intervals of twoweeks, counting from the date of seedling emergence of a previousplanting. Thus, the seedlings were raised to the ages of 4, 6 and 8 weeks, when they were to be inoculated with nematode larvae.

\section{Inoculation of the tomato plants}

Seventy two cylindrical plastic containers $(11 \mathrm{~cm}$ diameter) eachwith three drainage holes were respectively filled with $1 \mathrm{~kg}$ of thesterilized soil mixture. The holes were first covered with a piece offacial paper to prevent soil loss. The containers were labeledappropriately and arranged on the plant house benches in a 'completely randomized design' fashion. Spacing was $45 \mathrm{~cm}$ withinthe row and $60 \mathrm{~cm}$ between rows. The 4,6 and 8 weeks oldseedlings of the two tomato varieties were gently lifted from nurserysoil and transplanted into a small hole made at the centre of thepotted soil. The transplants were inoculated with 500, 1000 and 1500 nematode larvae suspension (slurry) as appropriate into thegroove made $5 \mathrm{~cm}$ away from each seedling. The control plantswere not inoculated. Nutrition was supplied to the plants byfertilization at 2 weeks interval throughout the duration of theexperiment by dissolving twenty grams $(20 \mathrm{~g})$ of a compoundfertilizer (N.P.K) in $30 \mathrm{~L}$ of tap water. The plants were watered asand when necessary.

\section{Experimental design}

A $2 \times 3 \times 4$ factorial experiment in completely randomized design(CRD) was performed to measure the effects of nematodeinoculums on two tomato varieties at different developmental ages.Factor A (plant age) was studied at 3 levels of 4, 6 and 8 weeks ofgrowth. Factor B (inoculum density) was studied at 4 levels of 500,1000 and 1500 and control levels. Factor $\mathrm{C}$ represented the twotomato varieties: $\mathrm{V}_{1}=$ Roma $\mathrm{VF}$ and $\mathrm{V}_{2}=$ wild tomato. 
Data collected

The following data were collected and recorded eight weeks afterinoculations:

i) Number of galls per root system.

ii) Number of galls per fresh weight of root (gram).

iii) Gall indices (G.I) at 0 to 5 scale.

iv) Days to $50 \%$ flowering after inoculation.

v) Root length per plant $(\mathrm{cm})$.

vi) Fresh weight of stem per plant (g).

vii) Shoot length per plant $(\mathrm{cm})$.

viii) Dry matter of root per plant (\%).

ix) Dry matter of stem per plant (\%).

x) Number of branches per plant.

The number of galls per root system was determined by countingwhile the number per fresh root weight (gram) was obtained fromthe values recorded from the root system. Shoot length wasobtained by measuring the length of the stem from the cotyledonarynode to the tip of the longest branch. Root length was measuredfrom the cotyledonary node to tip of the taproot. Percentage drymatter was obtained as the ratio of the dry weight to the freshweight expressed in percentage. For total dry matter determination,roots, and stem packed in separate envelopes and oven dried to aconstant weight at $60^{\circ} \mathrm{C}$ for $48 \mathrm{~h}$. Gall indices (G.I) were measuredaccording to IMP (1978) using the following scale: $\mathrm{O}=$ zero gall; $1=1$ or 2 galls; $2=3$ to 10 galls; $3=11$ to 30 galls; $4=31$ to 100 gallsand $5=>100$ galls per root system.

\section{Data analysis}

Data collected were subjected to analysis of variance for a CRDfactorial[20]. F-LSD was used for themeans separation aided by GenStat Release 7.22DE [21].

\section{Results}

Results on the effect of inoculum densities on meannumber of galls per root system of the varieties arepresented in Table 1 . The number of galls per rootsystem increased significantly $(\mathrm{P} \leq 0.05)$ with increases ininoculum densities. At the three stages (4, 6 and 8 weeks) of inoculation, Roma VF was significantly $(\mathrm{P} \leq 0.05)$ more susceptible to the nematode than the relativewild. Highest mean number of galls per root system onboth varieties occurred on those inoculated 6 weeks afterplanting. The first - order interactions; inoculum densitiessignificantly $(\mathrm{P} \leq 0.05)$ differed from tomato varieties andplant age significantly $(\mathrm{P} \leq 0.05)$ differed from tomatovarieties on their mean number of galls per root system. Results on the second - order interaction effect ofinoculum densities on mean of galls per root system ofthe two tomato varieties at different ages are presented inTable 1. The zero inoculum densities in both varieties atdifferent plant ages did not produced root galls. Theinteraction effect of 500 nematode larvae on two tomatovarieties at different ages produced mean number of rootgallsthat differed significantly $(\mathrm{P} \leq 0.05)$. The interactioneffect of 1000 and 1500 nematode larvae respectively onboth varieties on different plant ages produced a meangalls, statistically $(\mathrm{P} \leq 0.05)$ different from 500 inoculumdensities but did not differed significantly betweenthemselves. Generally, interaction effect increased withincreases in the inoculum densities. Table 2 shows theeffect of inoculum densities and plant age on meansnumber of days to $50 \%$ flowering of the tomato varieties.

Significantly, lower number of days to $50 \%$ floweringoccurred on uninoculated plants than the inoculated. Days to $50 \%$ flowering for plants inoculated with 1000 and 1500 larvae were the same but significantly higherthan those inoculated with 500 larvae of the nematode.Mean of days to $50 \%$ flowering also increasedsignificantly $(\mathrm{P} \leq 0.05)$ as age of plant at inoculationincreased. Roma VF at the different plant ages andnematode inoculum densities had significantly morenumber of days to $50 \%$ flowering than the relative wild.

There was no significant treatments interaction effect onthe mean number of days to $50 \%$ flowering of the tomatovarieties. Table 3 presents results of the effect ofinoculum levels and age on mean root length per plant $(\mathrm{cm})$ of the varieties. Different inoculum levels and plantages did not significantly affect mean root length perplant. Mean root length of the relative wild variety was however, significantly higher than that of Roma VF. No significant treatments interaction effect on the mean root length was observed. However, the uninoculated plants in both tomatoes had longer mean root length. The inoculated plants at all ages had reduced mean root lengths which differed significantly except V1 at 1,000 and 1,500. But the general trend is that inoculated plants had reduced root lengths and in majority of cases, proportionate to the amount of inoculum density. 
Table 1.Effect of inoculum density and plant age interaction on mean number of gall per root system of the two tomatovarieties at different ages

\begin{tabular}{clllllll}
\hline & \multicolumn{7}{c}{ Plant age (A) $\mathbf{~}$ Variety $(\mathbf{V})$} \\
\cline { 2 - 8 } Inoculum density & $\mathbf{A}_{\mathbf{4}} \mathbf{V}_{\mathbf{1}}$ & $\mathbf{A}_{\mathbf{4}} \mathbf{V}_{\mathbf{2}}$ & $\mathbf{A}_{\mathbf{6}} \mathbf{V}_{\mathbf{1}}$ & $\mathbf{A}_{\mathbf{6}} \mathbf{V}_{\mathbf{2}}$ & $\mathbf{\mathbf { A } _ { \mathbf { 8 } } \mathbf { V } _ { \mathbf { 1 } }}$ & $\mathbf{A}_{\mathbf{8}} \mathbf{V}_{\mathbf{2}}$ & Mean \\
\hline 0 & 0 & 0 & 0 & 0 & 0 & 0 & 0.00 \\
500 & 33 & 44 & 75.67 & 53.3 & 66.33 & 51.67 & 53.67 \\
1000 & 84 & 57 & 81.67 & 89.67 & 91.33 & 65.51 & 77.22 \\
1500 & 96.67 & 94 & 75.67 & 95 & 86.3 & 102 & 92.27 \\
Mean & 53.42 & 48.75 & 58.25 & 59.49 & 60.99 & 54.80 & \\
\hline
\end{tabular}

$\mathrm{F}-\mathrm{LSD}(\mathrm{P}=0.05)$, inoculums density $\times$ plant age $\times$ tomatoes varieties $=20.45 ;$ Symbol: $\mathrm{A}_{4} \mathrm{~V}_{1}=$ Roma $\mathrm{VF}$ at 4 weeks, $\mathrm{A}_{4} \mathrm{~V}_{2}=$ wild tomato at 4 weeks, $\mathrm{A}_{6} \mathrm{~V}_{1}=$ Roma $\mathrm{VF}$ at 6 weeks, $\mathrm{A}_{6} \mathrm{~V}_{2}=$ wild tomato at 6 weeks, $\mathrm{A}_{8} \mathrm{~V}_{1}=$ Roma $\mathrm{VF}$ at 8 weeks and $\mathrm{A}_{8} \mathrm{~V}_{2}=$ wild tomato at 8 weeks.

Table 2.Effect of inoculum density and age on mean number of days to $50 \%$ flowering of the varieties

\begin{tabular}{|c|c|c|c|c|c|}
\hline \multirow[b]{2}{*}{ Plant age } & \multirow[b]{2}{*}{ Inoculum density } & \multicolumn{2}{|c|}{ Tomato varieties } & \multirow[b]{2}{*}{ Mean } & \\
\hline & & $\overline{\operatorname{Roma} \text { VF }\left(\mathrm{V}_{1}\right)}$ & Wild type $\left(\mathrm{V}_{2}\right)$ & & \\
\hline \multirow{5}{*}{4 weeks } & 0 & 15.67 & & 9.67 & 12.67 \\
\hline & 500 & 19.00 & & 13.00 & 16.00 \\
\hline & 1000 & 21.00 & & 15.33 & 18.17 \\
\hline & 1500 & 21.00 & & 15.33 & 18.17 \\
\hline & Mean & 19.17 & & 13.33 & \\
\hline \multirow{5}{*}{6 weeks } & 0 & 16.67 & & 9.67 & 13.17 \\
\hline & 500 & 20.67 & & 13.67 & 17.17 \\
\hline & 1000 & 23.33 & & 16.67 & 20.00 \\
\hline & 1500 & 25.67 & & 18.00 & 21.83 \\
\hline & Mean & 21.58 & & 14.50 & \\
\hline \multirow{5}{*}{8 weeks } & 0 & 16.67 & & 10.33 & 13.50 \\
\hline & 500 & 22.33 & & 14.33 & 18.33 \\
\hline & 1000 & 25.00 & & 17.00 & 21.00 \\
\hline & 1500 & 26.00 & & 17.67 & 21.83 \\
\hline & Mean & 22.50 & & 14.83 & \\
\hline
\end{tabular}

$\mathrm{F}-\mathrm{LSD}(\mathrm{P}=0.05)$, inoculum density $=0.858$, plant age $=0.743$, tomato varieties $=0.607$, inoculum density $\times$ plant age $=\mathrm{NS}$, inoculum density $\times$ tomato varieties $=\mathrm{NS}$, plant age $\times$ tomato varieties $=1.051$ and inoculum density $\times$ plant age $\times$ tomato varieties $=$ NS .

Table 3.Effect of inoculums density and plant age on mean root length $(\mathrm{cm})$ of the varieties

\begin{tabular}{|c|c|c|c|c|c|}
\hline \multirow[b]{2}{*}{ Plant age } & \multirow[b]{2}{*}{ Inoculum density } & \multicolumn{3}{|c|}{ Tomato varieties } & \\
\hline & & $\overline{\operatorname{Roma} \text { VF }\left(\mathbf{V}_{1}\right)}$ & Wild type $\left(V_{2}\right)$ & Mean & \\
\hline \multirow{5}{*}{4 weeks } & 0 & 28.43 & & 37.27 & 32.49 \\
\hline & 500 & 22.43 & & 25.23 & 23.83 \\
\hline & 1000 & 27.73 & & 26.30 & 27.02 \\
\hline & 1500 & 25.70 & & 26.63 & 27.53 \\
\hline & Mean & 26.07 & & 28.86 & \\
\hline \multirow{5}{*}{6 weeks } & 0 & 27.13 & & 40.80 & 33.96 \\
\hline & 500 & 26.83 & & 37.30 & 33.82 \\
\hline & 1000 & 24.93 & & 35.13 & 30.03 \\
\hline & 1500 & 24.93 & & 33.40 & 29.17 \\
\hline & Mean & 25.96 & & 36.66 & \\
\hline \multirow{5}{*}{8 weeks } & 0 & 24.90 & & 40.27 & 32.59 \\
\hline & 500 & 21.07 & & 39.70 & 30.39 \\
\hline & 1000 & 24.37 & & 27.10 & 25.74 \\
\hline & 1500 & 19.27 & & 31.97 & 25.62 \\
\hline & Mean & 22.40 & & 34.76 & \\
\hline
\end{tabular}


$\mathrm{F}-\mathrm{LSD}(\mathrm{P}=0.05)$, inoculum density $=\mathrm{NS}$, plant age $=\mathrm{NS}$, tomato varieties $=3.428$, inoculum density $\times$ plant age $=\mathrm{NS}$, inoculum density $\times$ tomato varieties $=$ NS, plant age $\times$ tomato varieties $=$ NS and inoculum density $\times$ plant age $\times$ tomato varieties $=$ NS.

\section{Discussion}

In Roma VF and wild tomato, 1000 and 1500 nematodelarvae, respectively, produced the highest number of rootgalls at different plant ages. Following host penetration,generally near the root tip, nematodes migrateintercullarly to the region of cell differentiation [22]. The course of events thatfollow depends on the compatibility of the interactionbetween the nematode and the host plant. In asusceptible host, plant cells adjacent to the head of thenematode on large in response to stimuli form thenematode to form "giant cells" which are large,multinucleate, metabolically active cells that serve as asource of nutrients for the developing endo-parasitic formof the nematode[23]. Secretary glandcells in the nematode esophagus are the principalsources of secretions involved in plant parasitism, andthese gland cells enlarged considerably as nematodesevolved from microbial-feeding nematodes to becomeparasites of higher plants. Likewise the function of thesecretions produced by the esophageal gland cells alsoevolved to enable nematodes to feed on plant cells andmodify them into complex feeding cells [24 \& 25]. Recent discoveries also suggest thatsome genes encoding esophageal gland secretions ofplant-parasitic nematodes may have been acquired viahorizontal gene encoding esophageal gland secretions ofplant-parasitic nematodes may have been acquired viahorizontal transfer form prokaryotic microbes [26 \& 25]. This treatise focusesprimarily on discoveries made in identifying parasitiongenes in cyst and root-knot nematodes because thesenematodes induce the most dramatic and evolutionaryadvanced changes observed in host cell phenotype[27]. A number of genes withknown or ' $p$ ' putative functions have been found to be up- regulated or silenced in these feeding cells, suggestingthat root knot and cyst nematodes inducetranscriptional changes in the parasitized cells [28 \& 29]. The susceptibility ofthese varieties was indicated by high mean gall indices(more than $>: 15$ ). Root knot nematode damage generallyreduced root length which in turn reduced the area ofexploration for nutrients and water in soil.

The ability exhibited by $M$. incognita to locate andinvade tomato root may explain its aggressive nature inattacking the tomato. Its ability to induce severe galls inboth varieties could possibly rank it as an aggressivespecies in Abakaliki agro ecology. The susceptibility ofthe wild tomato in this work contradicts reports of Bailey[30]and Interiano and Quintanilla [16], which stated that L. pimpinellitoliumis not susceptible to root - knot nematode $-M$. incognita. Damaged roots are seriouslyhindered in their main functions of uptake and transport of water and nutrient. The induction of galls by root - knotnematodes in susceptible plants would impair theelongation of tap - root and proliferation of lateral roots[27]due to pathogenic effect on themeristematic tissue of the roots. When roots are impairedbyMeloidogynespp, water relations appear to contributesubstantially to reduce top growth. The prolonged periodof flowering in the inoculated plants of the two varietieswas statistically significant $(\mathrm{P} \leq 0.05)$ when compared to the uninoculated. The formation of galls in roots ofsusceptible plants disrupts the physiological functions ofroot xylem and phloem. The change from vegetativegrowth phase to reproductive phase in both tomatovarieties was delayed by $M$. incognita infection; henceflowering was probably delayed in susceptible plants dueto nutritional inadequacies.

Therefore, the duration of the vegetativephase may be prolonged by the deficiency of nutrients inthe rooting medium.

\section{References}

[1] P. Surya. Nitrogen effect on fruit set, yield and quality of heat tolerant tomato. 1993, P.121- 124. In: Training Report 1993. ARCAVRDC, Kasetsart University, Bangkok, Thailand.

[2] R. Villareal. Tomato production in the tropics. Problems and progress. In: R. Cowell (ed) proceedings of the 1st International Symposuim on Tropical Tomato AVRDC. Shanhua, Tainan, Taiwan. 1979, pp. 6-12.

[3] FAO. Food and Agricultural Organization. Annual Production Year Book. 1990

[4] N. Alfred. Tomato production in the tropics, problems and progress. In: R Cowell (ed). Proceeding of the first International Symposium on Tropical Tomato. ACRDC, Shanhua, Tainen. Taiwan. 1994, p. 6-12.

[5] N. Alfred. Temperature regulation on growth and development and tomato during ontogeny. In: R Cowell (ed). Proceedings of the first International Symposium on Tropical Tomato. AVRDC. 2004, pp. 79-93

[6] R. Ogbuji. Root-knot nematode infestation of cultural and nonsoils of Nsukka, Nigeria. The tropical country Writ magazine for the agriculture in the tropics and subtropics. 1980, 81(5):65- 69 .

[7] F. Lamberti. Economic importance of Meloidogyne species in tropical and Mediterranean climates, in: root-knot nematode Meloidogyne spp. Systematic, biology and control (eds. F. lamberti and C.E. Taylor Academic press, 1979.

[8] G. Bergeson. Mobilization of mineral to the infection site of root-knot nematodes. Phytopathol., 1966, 56: 1297-1289.

[9] M. Khan and M. Khan. Histophysiological alterations, induced by Meloidogyne incognita in tomato leaves. Int. Nematol. Network Hewsi. 1987, 4(4): 10-12.

[10] S. Meon, J. Fisher and H. Wallance. Changes in free praline following infection of plants with either Meloidogyne incognita or AgrobacteruimTumefaciens. Physiological Plant Pathology, 1978, 12:251-256.

[11] J. Aguiar, W. Williams, W. Graves, M. McGiffen, J. Samons, J. Ehlers and W. Matthew. Factor for estimating nitrogen contribution of cowpea as a cover crop. J. Agron. Crop Sci., 2001, 186: 145- 149.

[12] M. Ngouajio, M. Giffen and C. Hutchinson. Effect of Cover Crop and management system on weed populations in lettuce. Crop Prot. 2003, 22: 57-64 
[13] R. Robberts. The future of Nematology: integration of new and improved management strategies J. Nematol., $1993,25: 383$ - 394. (Medline)

[14] D. Kaur, R. Maliajan, D. Cheema and S. Sing. Screening of some F1 hybrids of tomato against root- knot nematode. Meloidogyne incognita in tomato pest management and economic zoology, 1994, 2(1): 95-96.

[15] H. Dabaj, N. El-Khwaildi, J. Mohammed and E. Edongali. Screening of some tomato and egg plant cultivars against root-knot nematode, Meloidogynejavanica, under field conditions of Libya Arab J. Plant Prot., 1996, 14(1): 44-46.

[16] M. Interiano and A. Quintanilla. Resquesta de Species mejorases de tomato silverstresLycopersiconpinpimellifoliumall parisitismoddelenematoadonodualdorMeloidogynesppNematropic 1972, 2: 19.

[17] International Meloidogyne Project (IMP). Guidelines for conducting Differential Host test for Meloidogyne Species, Section V. Proc. Res. Plan conf. Root-knot nematode, Meloidogyne Spp. Nematol Research Centre Cairo University. Giza. Egypt. Jan - Feb. 1978 , p.85

[18] M. Maurhofer, C. Keel, D. Haas and G. Defaso. Influence of plant species on disease suppression by pseudomonasfluorescens CHAO with enhanced antibiotic production, Plant Pathol., 1995, 44: 4050.

[19] R. Notz, M. Maurhoter, K. Schnider, B. Duffy, D. Haas and G. Defaso. Biotic factors affecting expression of the 2,4diacety/phloroglucinol biosynthesis gene phia in psendomonasfluorescensbiocontrol strain CHAO in the RhizospherePhytopathol., 2001, 91: 813-881.

[20] I. Obi. Introduction to Factorial Experiment for Agricultural, Biological and Social Sciences Research. 2nd ed. Optimal pubs. Enugu, 2001, p.92.

[21] I. Obi. Introduction to Factorial Experiment for Agricultural, Biological and Social Sciences Research. 3rd ed. Optimal pubs. Enugu, 2013, p.114. ISBN 9782039683.

[22] J. Eisenbback and H. Triantaphyllou. Root-knot nematodes: Meloidogyne species and races: In manual of Agricultural Nematology (Nickle, WR; ED). New York: Marcel Dekker, 1991, pp. 191- 274.

[23] H. Jeong - Yau, W. Rob, M. Helen, F. Monique, H. Kris and K. Moarten. The root - knot nematode resistance gene (Mi) in tomato: construction of a molecular linkage Map and identification of document CDNA, 1992.

[24] R. Hussey. Disease - inducing secretions of plant parasitic nematodes. Annu. Rev. Phytopath., 1989, 27 : 123-141.

[25] E. Davis, R. Hussey, T. Baum, J. Bakker, A. Schots, M. Rosso and P. Abad. Nematode parasitism genes. Annu. Rev. Psychopathol., 2000, 38:341-372.

[26] G. Smant, Y. Yan, J. Stokkermans, J. de Boer, E. Davis, H. Pomp, J. Zilverentart, H. Overmars, J. Helder, R. Hussey, A. Schots and J. Bakker. Endogenous cellulages in animals: Isolation of B- 1- 4- endogucanage sense from two species of plant parasitic cyst nematodes. Proc. Natl. Acad. Sci., USA, 1998, 95: 4906 - 4911.

[27] R. Hussey and F. Grundler. Henatode parasitism of plants. In:Perry R.N, wright D.J.(eds). Physiology and biochemistry of free living and plant parasitic nematodes CAB International press, England. 1998, pp. 213 - 243,

[28] D. Bird. Manipulation of host gene expression by root knot nematodes. J. Parasitol., 1996, 82: 881-888.

[29] G. Gheysen and C. Fenoll. Gene expression in nematode feeding sites. Annu. Rev. Phytopathol., 2002, 40: 124-168.

[30] D. Bailey. The seedling test method for root-knot-nematode resistance. Proc. Am. Soc. Hort. Sci., 1941, 38: 573-575. 